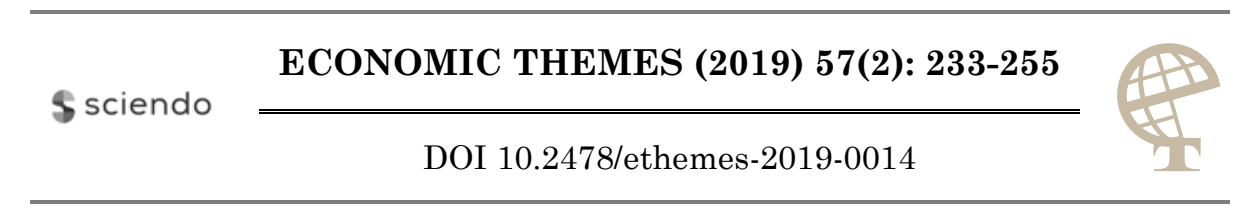

\title{
THE IMPACT OF THE COMMON AGRICULTURAL POLICY OF THE EUROPEAN UNION ON THE GENERAL PRICE LEVEL OF COUNTRIES THAT JOINED IN THE PERIOD FROM 2004 TO 2007
}

\author{
Ivana Stojanović
}

University of Niš, Faculty of Economics, Republic of Serbia

凶ivanastojanovic1512@gmail.com

UDC

338.43.02

(4-672EU)

Review paper

Received: 21.10.2018 Accepted: 30.05.2019

\begin{abstract}
Application of The Common Agricultural Policy (CAP) of the European Union implies the existence of a single market (without customs duties on mutual trade), the community's priority in meeting the needs for agricultural products (protection against imports) and the existence of financial solidarity (joint financing). Joining the European Union for new member states implies the termination of the implementation of the existing national agricultural policy and the the beginning of the implementation of the CAP. Although membership in the European Union implies many advantages, the period after joining this community can be quite economically unstable for some countries. One of the most significant problems is an increase in agricultural product prices and a rise in the general price level (inflation). The above can be confirmed by a simple empirical analysis of the economic indicators of the countries that joined the EU together in the period from 2004 until 2007.
\end{abstract}

Keywords: agrocultural policy, CAP, EU, European Union, inflation, general price level.

JEL classification: Q14, Q18

\section{Introduction}

Joining the European Union, as one major economic system that brings significant benefits to its members, leads to a number of changes in the new member states. Some of these changes may initially have an adverse impact on the economies of these countries. Joining the EU implies also a common agricultural policy of all member states, with a number of changes in the existing legal regulations of new members and adjustment of prices of agricultural products to the prices of other member states. In most of these countries, agriculture has greater relative importance than in the EU in terms of Gross Domestic Product (GDP) and employment (Fernández, 2002). As agricultural products make up a significant part 
of the consumer basket of the population of developing countries, changes in the prices of these products also affect the general level of prices of these countries. Namely, the share of food prices in the consumer price index (CPI) of developing countries is about $30 \%$ on average. Developed economies are more resistant to food price movements, as the participation of these prices in the CPIs of these countries is about $13 \%$ on average (Cecchetti \& Moessner, 2008).

Common Agricultural Policy is one of the most important EU policies, and its share of budget allocation is the largest. It is therefore not surprising that the negotiations on agricultural policies with the applicant countries are often seen as the most controversial in the enlargement process (Fernández, 2002). Leaving the system of government price control leads to a large increase in retail prices, which increases the already existing level of inflation in these countries. This increase in inflation caused by an increase in food prices, is being accompanied by an increase in inflation caused by inflationary expectations and inadequate monetary policy. Namely, changes in food prices are often happening in a very short time, and monetary policy delivers results with a big time lag. On the other hand, even if a food price shock is expected, the restrictive monetary policy response with the ambition to reduce the price shock resulting from food prices and quickly return the prices to the previous level, is most often overstated and almost certainly leads to a significant general decline in GDP and the level of employment (Šoškić, 2015). However, as mentioned above, this is a short-term phenomenon, which is accompanied by an increase in productivity, improved product quality and competitiveness, and finally, price stabilization and lower inflation.

The aim of this paper is to point out the significance of the agricultural sector and the agricultural policy for the economy and the stability of the prices of countries, by observing the inflationary effects which The EU's Common Agricultural Policy was having in the countries that joined the European Union in the period 2004-2007. The starting hypothesis is that EU accession in the short term leads to a rise in the prices of agricultural products of new members, which has a negative impact on inflation in these countries.

\section{Theoretical framework of the research}

In order to confirm the starting hypothesis, in the continuation of the paper, basic scientific methods such as abstraction and concretization were used, and in particular the comparison method, i.e. the comparison of empirical data on the movement of individual indicators in the period 2000-2007 in the 10 new EU Member States (Bulgaria, Czech Republic, Estonia, Hungary, Latvia, Lithuania, Poland, Romania, Slovakia, Slovenia) with cumulative data from the old EU member states (EU15). Considering the uncertainty of the EU accession of Serbia as well as insufficient emphasis on the importance of the agricultural sector, only a small number of domestic researchers (eg Soskic and Milanovic) deal with the 
question of the interaction between food prices and inflation. On the other hand, due to the significant changes brought about by the accession of the EU, the countries that themselves later joined the EU, published a number of scientific publications dealing with ex post analysis of the impact of the EU and the Common Agricultural Policy. In addition to the members themselves, a number of papers were published by the most important economic organizations such as OECD and FAO, and the European Commission has provided a number of statistical data available at Eurostat.

The structure of this scientific work is the following. The first part of the paper points to the specificity of supply and demand, and therefore the prices of agricultural products, as well as the necessity of government interventions. The most commonly applied measures and instruments for implementing certain agricultural policies are also presented. The second part presents the basic objectives and principles of the Common Agricultural Policy of the European Union. In the third part, the authors provide numerous empirical data on the movement of prices of the most important agricultural products as well as the factors of production in the new EU member states. In the fourth part, the analysis of empirical data points to the significant participation of agricultural products in consumer baskets of individual countries, and the share of inflation in agricultural products in total inflation in the new EU member states by the years of the observed period.

\subsection{Measures and effects of agricultural policy measures on prices of agricultural products and the common agricultural policy of the European Union}

The supply and demand imbalance is particularly pronounced in agricultural products due to the existence of seasonal oscillations in production, and therefore also in supply. Namely, agricultural products are produced seasonally and being spend continuously throughout the year, which leads to a large mismatch between supply and demand for these products. Demand for agricultural products is a derived demand. It is defined by the attitude of consumers towards products of higher processing. Hence, the specifics of demand for agricultural products also determine the specific conditions for the development of agro-industry as a whole (Zakić \& Stojanović, 2008).

In the long run, the supply of agricultural products is higher than demand (which is inelastic), which means that prices of agricultural products tend to decline. As a result, the relations between prices of agricultural products and industrial inputs used in agriculture (fertilizers, fuels, etc.) are distorted, to the detriment of agricultural products (Božić et al., 2011). Taking into account the fact that agricultural products meet the basic human need for food and significantly 
affect the standard of living of the population, it is clear why government intervention in the field of agriculture is necessary.

There are numerous instruments, that is, measures of agricultural protectionism applied in certain countries, which can all be grouped as:

- import restriction - implemented using measures such as: customs duties, levies, various forms of quantitative restrictions on imports, the application of different exchange rates, qualitative restrictions (standards), etc.;

- encouraging exports - achieved through the following measures: export subsidies, the use of multiple exchange rates, state trade arrangements, etc.;

- direct incentives for domestic production - is achieved by subsidising domestic production, primarily by applying higher prices than actual market prices on the domestic or international market. The most common forms of subsidies are: premiums, reimbursements, tax deductions, etc. (Božić et al., 2011).

In addition to the aforementioned, domestic agricultural production can be influenced by numerous other measures aimed at regulating the supply or demand for agro-food products.

Direct support for prices of agricultural products is achieved through the establishment of guaranteed prices of strategic agricultural products and ensuring the realization (purchase) of all surpluses of supply on the domestic market. Guaranteed prices are prices guaranteed by the government and are usually lower than market prices. They are identified for the most important (strategic) agricultural products (mostly cereals, meat, milk, basic industrial cultures). If the price level decreases below the guaranteed level, the government is obliged to purchase all offered quantities at guaranteed prices. If, due to the reduced supply, the market prices of the products are growing, their reduction is compensated by taking out the missing quantities of goods from commodity reserves or by intervention imports.

In addition to the guaranteed prices, the so-called target or orientation prices can be determined so that the market prices of individual products are maintained around that target level. The farmer then receives direct payments from the budget that represent the difference between the target and the market or the security price. In this case, the producer is stimulated to produce up to the point where his/her marginal costs are equated with the previously known target, rather than the expected market price.

Export encouraging aims to reduce surpluses on the market and maintain a certain level of agricultural product prices. Namely, due to the previously mentioned direct support system, producers are stimulated to produce large volumes (creating huge product surpluses), but they are not stimulated to export these surpluses, because of the existing high prices of these products on the domestic market. The redemption of these surpluses leads to high costs in the 
budget and the destruction of large quantities of agricultural products, in order to prevent a fall in their prices. The solution to this problem is subsidising the export of agricultural products.

The import restriction is also aimed at maintaining the achieved level of domestic product prices by preventing excessive imports of products at lower prices than the prices of domestic products. Concerning the concrete measures to achieve this, the most important are customs duties, excises, levies, quantitative restrictions (contingents, quotas). Customs duties represent the type of indirect tax on goods crossing the border, and are usually determined as a percentage of the value of goods or units of measurement. Excise taxes are also a type of indirect tax that is paid on imported but also on domestic products (tobacco products, alcoholic beverages, coffee, etc.). The levies are determined as the difference between the lower import price increased for customs and manipulative costs and higher domestic price. Quotas represent the determined volume of products within which lower customs rates are applied.

Restricting the supply of agricultural products is carried out in order to prevent a fall in prices due to an increase in the supply of agricultural products. Some of the measures used are: determining production quotas, state support for abandoning production and withdrawing resources, resting land (change of purpose), supporting organic production (which yields less yields), etc.

Increasing demand for agricultural products can be achieved by increasing domestic and export demand. The objective of increasing demand may be to increase prices or increase the production of agricultural products.

The Common Agricultural Policy (CAP), as an agricultural policy established at the EU level, also applies the aforementioned measures and instruments in order to achieve its main objectives, which are (Andrews, 2009):

- increasing productivity in agriculture. Europe should be self-sufficient in food production and should not rely on food imports from other regions;

- guaranteeing acceptable food prices both for manufacturers and for European consumers;

- ensuring a decent living standard for the rural population by increasing income in agriculture;

- market stabilization. The agricultural product market is quite unstable. In order to provide security to those who rely on agricultural product revenues, CAP should form the so-called safety net and thus, reduce market fluctuations.

These goals have not changed as much as one could expect during the half century that the CAP has been up and running. New goals have been added and given increased importance though, like environmental concerns (Rydén et al., 2013).

In order to achieve these goals, CAP has defined its basic principles: 
- a single market that involves the elimination of customs barriers and other trade barriers and the free flow of goods between member states. The single market also assumes the establishment of common prices and the same competition rules. In order to ensure the smooth exchange of agricultural and food products in the unique European market, a high level of harmonization of administrative provisions, as well as standards in the field of sanitary and veterinary control had to be achieved;

- the priority of the community whose essence is the EU's bid to protect its market from imports. In connection with this, from the level of member states, authorizations for determining the priority given to the placement of domestic products through one national market, have been transferred to the community level. Thus, through the domination of the community, it is possible to protect the domestic market from excessive imports of agricultural and food products at low prices from third countries, thereby saving the income of European farmers.Also, by applying the appropriate system of import and export instruments, protection against fluctuations in prices on the world market has been ensured and satisfactory supply stability has been established;

- financial solidarity presupposes securing the necessary financial resources at the community level to finance the operationalization of CAP measures. In this regard, in order to finance its agricultural policy, the EU has set up a fund, which is aligned with the contribution of all six member states, and whose funds were used to cover the expenditure incurred in the functioning of the CAP(Đurić \& Njegovan, 2016).

CAP EU is implemented through two basic groups of measures and instruments, which form the CAP pillars: market pricing policies or the first pillar, and structural measures, or measures to improve the development of rural areas which are the second pillar of the CAP.

The first pillar, i.e. the market pricing policy, contains a number of different measures that can be divided into two large groups: market interventions (foreign trade measures - import protection and export incentives, intervention purchase, storage, production quotas, etc.) and direct payments (per hectare, throat cattle, farms).

The second pillar of the CAP is the rural development policy measures that support multifunctionality of agriculture, that is, they encourage the efficiency and competitiveness of agriculture; improvement of the environment and rural environment; as well as improving the quality of life in rural areas and encouraging the diversification of the rural economy (Božić et al., 2011).

The great importance of CAP is confirmed by the fact that CAP represents the most expensive EU-implemented policy, and therefore it deserves a special attention. In addition to the positive effects, the realization of the set objectives of the CAP has produced certain negative effects. Therefore, CAP has been subject to many changes and reforms since its establishment. 


\subsection{The impact of the accession of New EU Members on the prices of their agricultural products}

A necessary condition for the normal functioning of the economy of each country is the establishment of economic relations with foreign countries, that is, global economic cooperation. The enlargement of the European Union in 2004 was the largest enlargement of the European Union (EU) in terms of territory, number of countries and population to date. The enlargement took place on May 1, 2004. At the same time, the following countries joined: Cyprus, the Czech Republic, Estonia, Hungary, Latvia, Lithuania, Malta, Poland, Slovakia and Slovenia. Part of the same wave of enlargements was the accession of Bulgaria and Romania in 2007, which were unable to join in 2004, but, according to the Commission, they are part of this extension. Due to the lack of data, the analysis carried out an analysis of 10 countries (without Cyprus and Malta).

However, it should be emphasised that during the observed period, in addition to the EU, there were many other factors that influenced the growth and fluctuation of the prices of all countries, both old and new, in the EU. The fast-growing Asian economies, population growth, turmoil in the Middle East and the entire Arab world have contributed to a significant increase in food and energy prices in observed years. More precisely, after a relatively stable period of 2000-2003, food prices rose rapidly. As it can be seen, growth was not linear, but with large oscillations (especially in the period 2008-2010), but with a clear upward trend (Milanović et al., 2011).

Figure1. FAO world food price index in the period 2000-2017

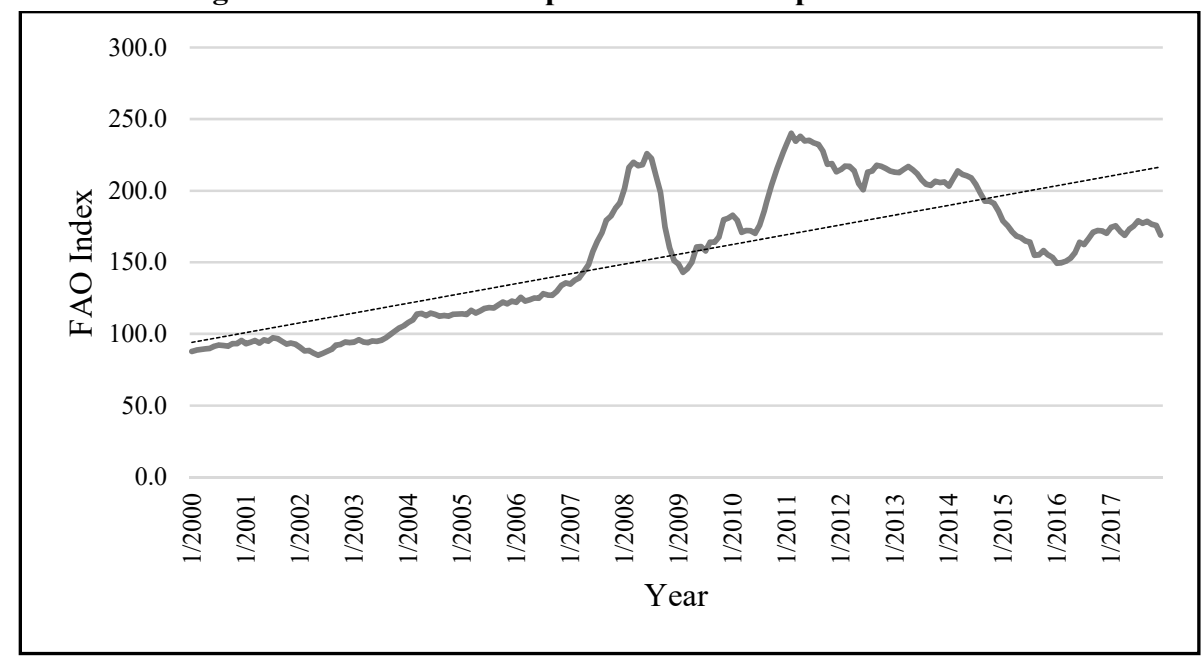

Source: FAO Food Price Index (2017) http://www.fao.org/worldfoodsituation//foodpricesindex/en/ 
In addition, a significant contribution to the increase in food prices has also been given to increased demand and production of biofuels (Milanović et al., 2011). Some studies (Price Volatility in Food and Agricultural Markets, 2011) have also shown another significant variable that influences food prices in the world. It is a fact that food prices correlate with oil price movements. Oil prices affect food prices directly (through prices of raw materials, fuels and fertilizers) and indirectly, as higher oil prices increase demand for biofuels (biofuel production becomes profitable), which further creates a pressure on food prices. Also, the more pronounced climate change has increased uncertainty in terms of expectations of future prices (Cantore, 2012), which led to higher instability and rising food prices.

Table1. Inflation of food prices in new EU member states in the period 2001-2017

\begin{tabular}{ccccc}
\hline Country & $\mathbf{2 0 0 1 - 2 0 0 3}$ & $\mathbf{2 0 0 4 - 2 0 0 7}$ & $\mathbf{2 0 0 8 - 2 0 1 2}$ & $\mathbf{2 0 1 3 - 2 0 1 7}$ \\
\hline Bulgaria & 1,9 & 7,8 & 5,1 & 1,0 \\
\hline Czech Republic & 0,6 & 2,3 & 3,6 & 2,2 \\
\hline Estonia & 3,4 & 5,6 & 5,1 & 2,0 \\
\hline Hungary & 2,9 & 7,3 & 6,0 & 1,1 \\
\hline Latvia & 4,0 & 9,8 & 5,5 & 1,4 \\
\hline Lithuania & 0,0 & 6,1 & 5,6 & 1,4 \\
\hline Poland & 1,1 & 3,5 & 4,5 & 0,9 \\
\hline Romania & 16,6 & 5,9 & 4,8 & $-0,2$ \\
\hline Slovakia & 3,5 & 2,7 & 3,0 & 0,8 \\
\hline Slovenia & 7,3 & 2,2 & 3,9 & 1,5 \\
\hline New members average & 4,1 & 5,3 & 4,7 & 1,2 \\
\hline EU15 & 3,4 & 1,6 & 2,4 & 0,9 \\
\hline
\end{tabular}

Source: Calculations by the author. Based on Eurostat, European Comission.

Price increases can also be noticed in EU countries, especially in countries that joined the EU in the period 2004-2007 (Table 1).

When it comes to the countries that joined the EU in the period 2004-2007, the previous factors that contributed to the increase in the price of food should also include significant changes in the labor force (Table 2).

In 2003, more than 7 million workers were employed in new EU member states in agriculture. After joining the EU, the number of employed in agriculture has decreased by as many as 1 million workers in just 4 years. Employment in agriculture in Bulgaria has decreased by almost $40 \%$. A reduction of more than $20 \%$ was recorded in Latvia, Slovakia and Hungary. Poland is the only country in which the number of employees in agriculture since joining the EU in 2007 increased in relation to 2003, after which there was also a decrease. This reduction in the labor force in the agricultural sector has influenced the increase in labor costs 
and the increase in prices of agricultural products. Labor reductions are also recorded in the EU15 countries, but to a significantly lesser extent than in the new Member States.

Table 2.Changes in agricultural labor in EU member states in the period 2000-2017

\begin{tabular}{cccccc}
\hline Country & $\mathbf{2 0 0 0}$ & $\mathbf{2 0 0 3}$ & $\mathbf{2 0 0 7}$ & $\mathbf{2 0 1 2}$ & $\mathbf{2 0 1 7}$ \\
\hline Bulgaria & 771 & 792 & 494 & 347 & 236 \\
\hline Czech Republic & 166 & 151 & 127 & 106 & 105 \\
\hline Estonia & 65 & 39 & 33 & 23 & 20 \\
\hline Hungary & 676 & 582 & 459 & 433 & 75 \\
\hline Latvia & 149 & 141 & 107 & 84 & 147 \\
\hline Lithuania & 187 & 187 & 158 & 145 & 421 \\
\hline Poland & 2495 & 2279 & 2299 & 1915 & 1676 \\
\hline Romania & 3645 & 2696 & 2205 & 1573 & 1502 \\
\hline Slovakia & 143 & 119 & 91 & 57 & 79 \\
\hline Slovenia & 104 & 96 & 84 & 81 & 44 \\
\hline New members total & 8400 & 7080 & 6059 & 4765 & 4304 \\
\hline EU15 total & 6440 & 6058 & 5582 & 5033 & 4823 \\
\hline Source: Cacution
\end{tabular}

Source: Calculations by the author. Based on Eurostat, European Comission.

\subsubsection{Prices of cereals}

Prices in the cereals market in the new EU member states were different and fluctuating in the period 2000-2007 (Table 3). Before joining the EU, cereals prices were significantly below the EU level (eg in 2000, in Slovakia, 30\% lower prices), with the exception of Slovenia and Romania.

Table 3. Cereals prices in new EU member states in the period 2000-2017, euro/ton

\begin{tabular}{cccccc}
\hline Country & $\mathbf{2 0 0 0}$ & $\mathbf{2 0 0 3}$ & $\mathbf{2 0 0 7}$ & $\mathbf{2 0 1 2}$ & $\mathbf{2 0 1 7}$ \\
\hline Bulgaria & 88 & 99 & 127 & 189 & 150 \\
\hline Czech Republic & 93 & 122 & 172 & 216 & 161 \\
\hline Estonia & 91 & 93 & 165 & 186 & 129 \\
\hline Hungary & 108 & 108 & 168 & 199 & 130 \\
\hline Latvia & 101 & 90 & 165 & 187 & 134 \\
\hline Lithuania & 89 & 98 & 163 & 183 & 132 \\
\hline Poland & 105 & 92 & 162 & 183 & 136 \\
\hline Romania & 131 & 133 & 206 & 238 & 169 \\
\hline Slovakia & 85 & 95 & 162 & 185 & 147
\end{tabular}




\begin{tabular}{cccccc}
\hline Slovenia & 135 & 144 & 180 & 208 & 154 \\
\hline EU15 average & 119 & 117 & 177 & 222 & 169 \\
\hline *Categories of cereals included: soft wheat, rye, barley and oats. \\
Source: Calculations by the author. Based on Eurostat, European Comission.
\end{tabular}

After joining, there was a rapid adjustment of cereals prices and their approximation to the level of the EU15, with the highest price increase occurring in Slovakia where prices in 2007 compared to 2000 increased by as much as $91 \%$. In the Czech Republic, Lithuania and Estonia, prices also rose by more than $80 \%$. Here, however, we should mention the price increase in the EU15 countries in the same period of as much as $49 \%$, which is in line with the tendencies of increasing the prices of cereals around the world due to the weather and market conditions at that time.

On average, the difference between the prices of the EU15 countries and the new members in 2000 was about $14 \%$, while after joining the EU this difference was reduced to only $6 \%$. In the years after the joining, there is again a bigger fall in prices in the new member states compared to the EU15, so that the average price in the new members in the period 2008-2017 was about 13\% lower, almost the same as before the application of CAP. It concludes that the negative impact of CAP on new members, when the prices of cereals are at stake, was short-termed.

\subsubsection{Prices of meat}

Meat prices were significantly below the EU15 prices before accession (from 35$55 \%$, except in Slovenia, 9\%). After joining the EU, meat prices were extremely different.

Table 4. Meat prices in new EU member states in the period 2000-2017, euro/ton

\begin{tabular}{cccccc}
\hline Country & $\mathbf{2 0 0 0}$ & $\mathbf{2 0 0 3}$ & $\mathbf{2 0 0 7}$ & $\mathbf{2 0 1 2}$ & $\mathbf{2 0 1 7}$ \\
\hline Bulgaria & 681 & 791 & 1016 & 1221 & 1075 \\
\hline Czech Republic & 878 & 960 & 1544 & 1667 & 1392 \\
\hline Hungary & 893 & 1225 & 1286 & 1689 & 1202 \\
\hline Latvia & 978 & 796 & 1078 & 1348 & 1202 \\
\hline Lithuania & 942 & 908 & 1133 & 1435 & 1214 \\
\hline Poland & 1226 & 1141 & 1665 & 1691 & 1554 \\
\hline Romania & 972 & 1115 & 1025 & 1277 & 1240 \\
\hline Slovakia & 950 & 959 & 1137 & 1386 & 1275 \\
\hline Slovenia & 1378 & 1305 & 1393 & 1837 & 1654 \\
\hline EU15 average & 1518 & 1360 & 1511 & 1872 & 1903 \\
\hline $\begin{array}{l}\text { *Categories of meat included: young cattle, calves, pigs, sheep and chickens. } \\
\text { *Missing data for Estonia. }\end{array}$ & & & \\
\hline
\end{tabular}


Source: Calculations by the author. Based on Eurostat, European Comission

Accession has brought significant price increases in all countries (Table 4). Prices were getting closer, but they remained largely below the level of the EU15 (on average about 17\% lower). However, the increase in meat prices in the observed period is significantly lower in the EU15 than in the case of cereals. Contrary to the growth in prices in the new EU member states of $29 \%$ in the same period in the EU15 countries, there are no price changes. The highest percentage increase was recorded in Bulgaria (49\%), although prices remained below the level of the EU15 (55\% lower than the EU15 average).

The period after 2008 is characterised by an increase in prices in the EU15 countries as well as in new member states, but with this increase in prices in the new member states not accompanied by an increase in prices in the EU15 to the same extent, so that the difference between the prices of EU15 countries and new member states has increased again (in 2017, 31\% lower prices than the EU15 average). Similar to cereals, only the short-term impact of CAP on meat prices in new members was noticed, after which a fall in prices in relation to EU15 prices occured.

\subsubsection{Prices of milk}

Milk prices show significant diversity in individual countries before accession. In some countries such as Slovenia and Hungary, domestic prices were close to the level of the EU15 (Table 5). On the other hand, in Romania prices were about 2.5 times lower than the level of the EU15. Joining the EU brought price adjustments in this sector as well. Obviously, the biggest adjustments occurred in countries with the lowest preaccession prices, namely Romania, Lithuania and Latvia. The reason for this increase in milk prices in these countries was a significant reduction in production volumes.

Table 5. Milk prices in new EU member states in the period 2000-2017, euro/ton

\begin{tabular}{cccccc}
\hline Country & $\mathbf{2 0 0 0}$ & $\mathbf{2 0 0 3}$ & $\mathbf{2 0 0 7}$ & $\mathbf{2 0 1 2}$ & $\mathbf{2 0 1 7}$ \\
\hline Bulgaria & 173 & 169 & 250 & 318 & 335 \\
\hline Czech Republic & 210 & 244 & 296 & 310 & 321 \\
\hline Estonia & 174 & 184 & 269 & 301 & 317 \\
\hline Hungary & 242 & 282 & 289 & 304 & 312 \\
\hline Latvia & 156 & 150 & 243 & 258 & 291 \\
\hline Lithuania & 136 & 135 & 247 & 243 & 275 \\
\hline Poland & 190 & 159 & 275 & 286 & 327 \\
\hline Romania & 136 & 152 & 323 & 331 & 379 \\
\hline
\end{tabular}




\begin{tabular}{cccccc} 
Slovakia & 197 & 222 & 290 & 309 & 310 \\
\hline Slovenia & 280 & 275 & 278 & 300 & 310 \\
\hline EU15 average & 337 & 357 & 367 & 360 & 364 \\
\hline *Categories included: all categories of cows' milk.
\end{tabular}

Source: Calculations by the author. Based on Eurostat, European Comission.

Differences in domestic prices and the varying degree of impact are the result of differences in national policies. A high level of support before joining the EU in Hungary and Slovenia brought prices close to the level of the EU15 and, consequently, to a minimal adjustment of prices for producers (Csaki \& Jambor, 2009).

Finally, similar to the price of cereals and meat prices, and milk prices in the new member states also grew much more in the period after accession $(53 \%$ from 2000-2007) compared to the EU15 countries (only 9\%). In 2007, the prices in the new member states were closer to the prices of the EU15, so that the difference between the prices of the EU15 and new members was reduced from $44 \%$ in 2000 to $25 \%$ in 2007 . However, unlike the prices of cereals and meat prices, in the period 2008-2017, milk prices continued to rise in the new member states, so that the difference between the prices of the EU15 and new members was $15 \%$ on average. Therefore, when it comes to milk prices, it can be concluded that the application of CAP has led to a long-term adjustment of milk prices in new member states to the milk prices of the EU15 countries.

\subsection{Impact of agricultural product prices on the general price level}

Inflation, as an increase in the general price level, can be caused by a number of factors acting jointly, so that their individual contribution is difficult to measure. Increasing the price of parts of the consumer basket that make up a significant part of it and are of crucial importance for the standard of living of the population, can greatly contribute to the increase in the rate of total inflation in one country. Agricultural-food products, given their specificity and the fact that they serve to meet basic living needs, make up the bulk of the consumer basket in most countries, and therefore contribute the most to inflation.

It should be noted that higher food prices can have a large indirect impact on inflation. Especially the inflation expectations should be noted here. It is normal to assume that economic agents are looking ahead when it comes to making decisions. If wage earners anticipate high inflation, they will demand higher wages than if they expect low inflation. Likewise, enterprises will raise their prices further if they anticipate high inflation.Higher food prices can, therefore, put pressure on other prices and wages via higher inflation expectations (Tove \& Stoholen, 2008). 
Most of the countries that joined the EU in the period 2004-2007 had a high level of food consumption in the consumer basket, and it can easily be seen on the example of these countries that the increase in prices in the period after joining the EU has affected the rise in the general price level in these countries.

When it comes to increasing food prices as a cause of inflation, some factors affect the inflation rate depending on the time horizon. Over the short term, the structure of the consumption basket plays an important role for headline inflation. For example, for given commodity price shocks, headline inflation will be higher in countries with higher energy and food price shares in the consumer basket. Over the medium term, business cycle fluctuations are important determinants of inflation. Administered prices and indirect tax changes may also contribute to country-specific inflation over the medium-term, as new member states policies are synchronised with the EU requirements. Over the longer term, factors such as convergence of price levels across countries become a more important driving force. $^{1}$

It can be noted that a significant part of total inflation in the new EU member states is caused by common factors, such as price levels and EU integration. Factors specific to certain countries also played a significant role in creating inflation. These factors relate to the specific financial conditions, the price level, the current situation between supply and demand in a country, and so on, although adjustments to administrative prices and the increase in indirect taxes associated with EU accession have also played a significant role.

The new EU member states are more energy intensive and have a significantly higher share of food prices in their consumer basket than the old EU member states (Table 6). Thus, the share of food in the basket of consumers in the new member states in the period 2001-2003 was on average 80\% higher than in the EU15. The largest share of food is observed in Bulgaria and Romania (over 39\%), as well as in Lithuania and Latvia (over 25\%). The average food participation in the new member states in the period 2001-2003 was $26.6 \%$, while in the period after accession from $2004-2007$ it was reduced to $21.8 \%$.

Table 6. New and old EU member states: Share of energy, liquid fuels and food in the consumer basket in \%, average values in the period 2001-2007

\begin{tabular}{ccccccc}
\hline Period & \multicolumn{3}{c}{ 2001-2003 } & \multicolumn{3}{c}{ 2004-2007 } \\
\hline Country & Energy & $\begin{array}{c}\text { Liquid } \\
\text { fuel }\end{array}$ & Food & Energy & $\begin{array}{c}\text { Liquidfu } \\
\text { el }\end{array}$ & Food \\
\hline Bulgaria & 14,9 & 3,1 & 39,9 & 14,5 & 5,8 & 25,6 \\
\hline Czech Republic & 13,5 & 3,4 & 18,1 & 13,8 & 4,0 & 16,7 \\
\hline
\end{tabular}

${ }^{1}$ What drives inflation in the New EU Member States? (2008) Occasional Papers No. 50, Staff of the Directorate-General for Economic and Financial Affairs, European Commission, Brisel., p. 12. 


\begin{tabular}{ccccccc} 
Estonia & 13,0 & 5,3 & 22,1 & 12,7 & 5,6 & 19,5 \\
\hline Hungary & 14,4 & 5,3 & 19,1 & 13,0 & 5,0 & 17,7 \\
\hline Latvia & 13,0 & 3,0 & 29,6 & 12,0 & 4,0 & 25,1 \\
\hline Lithuania & 12,8 & 4,0 & 31,4 & 13,4 & 4,9 & 25,1 \\
\hline Poland & 14,3 & 3,8 & 27,0 & 16,1 & 5,6 & 18,7 \\
\hline Romania & 17,9 & 4,0 & 39,4 & 18,6 & 3,9 & 36,4 \\
\hline Slovakia & 12,9 & 3,7 & 20,5 & 18,0 & 3,4 & 16,7 \\
\hline Slovenia & 15,4 & 7,9 & 18,4 & 12,6 & 8,2 & 16,1 \\
\hline New members average & 14,2 & 4,3 & 26,6 & 14,5 & 5,0 & 21,8 \\
\hline EU15 average & 8,7 & 4,9 & 14,8 & 8,9 & 5,0 & 13,8 \\
\hline
\end{tabular}

Source: Calculations by the author. Based on Eurostat, European Comission.

In the following period, from 2008-2017, the decrease in the share of food in the consumer basket of new member states continues, so in the period from 2008 to 2012 it was $20.3 \%$, in the period 2013-2017 it was $19.4 \%$, while the share of food in the EU15 consumer basket in the period from 2000 to 2017 was almost unchanged. Thus, the difference of $11.8 \%$ between the share of food in the consumer basket in the new member states and the EU15 was reduced to only $5.7 \%$. On the other hand, when it comes to the participation of energy and liquid fuels, it can be noticed that there are no significant changes either in the new EU Member States or in the EU15.

Table7. New and old EU member states: Share of energy, liquid fuels and food in the consumer basket in \%, average values in the period 2008-2017

\begin{tabular}{ccccccc}
\hline Period & \multicolumn{3}{c}{$\mathbf{2 0 0 8 - 2 0 1 2}$} & \multicolumn{3}{c}{$\mathbf{2 0 1 3 - 2 0 1 7}$} \\
\hline Country & Energy & $\begin{array}{c}\text { Liquidfu } \\
\text { el }\end{array}$ & Food & Energy & $\begin{array}{c}\text { Liquidfu } \\
\text { el }\end{array}$ & Food \\
\hline Bulgaria & 13,4 & 7,7 & 19,9 & 12,9 & 7,7 & 18,8 \\
\hline Czech Republic & 14,0 & 4,1 & 15,6 & 13,9 & 3,8 & 16,5 \\
\hline Estonia & 13,3 & 4,8 & 19,9 & 13,0 & 4,4 & 19,0 \\
\hline Hungary & 14,8 & 5,9 & 17,3 & 16,0 & 8,1 & 17,9 \\
\hline Latvia & 13,6 & 5,2 & 22,1 & 14,9 & 5,7 & 21,3 \\
\hline Lithuania & 14,3 & 5,6 & 23,3 & 13,7 & 7,0 & 20,8 \\
\hline Poland & 13,6 & 4,2 & 19,8 & 14,7 & 4,9 & 17,2 \\
\hline Romania & 16,4 & 4,4 & 32,9 & 12,3 & 5,6 & 29,5 \\
\hline Slovakia & 16,6 & 2,8 & 16,3 & 15,5 & 2,4 & 17,1 \\
\hline Slovenia & 13,5 & 8,4 & 15,3 & 13,6 & 7,9 & 15,6 \\
\hline New members average & 14,4 & 5,3 & 20,3 & 14,0 & 5,7 & 19,4 \\
\hline
\end{tabular}




\begin{tabular}{lllllll}
\hline EU15 average & 10,0 & 5,6 & 13,6 & 9,8 & 5,4 & 13,7 \\
\hline
\end{tabular}

Source: Calculations by the author. Based on Eurostat, European Comission.

In line with the above, food price jumps have had a much more pronounced effect on total inflation in the new EU member states than in the old EU member states. Figure 2 shows that in the period prior to the accession of new members the EU15, food inflation had somewhat greater effect on total inflation (on average about 19\%), while the impact of food inflation on total inflation in the EU15 countries has significantly decreased in the period after the entrering of new members (on average about $10 \%$ ). The situation is completely opposite when it comes to the share of energy inflation in total inflation. Without taking into account the high share of food inflation in 2008 (which was present worldwide, not only in the EU), it can be noticed, observing the next period until 2017, that food inflation in the EU15 was not particularly important. This is in line with the previously mentioned low food share in the EU15 total consumer basket. On the other hand, energy inflation in the EU15 also in the next observed period until 2017 had much more significance, i.e. much more contributed to total inflation than food inflation.

Figure 2. The share of food and energy prices inflation in total inflation in the EU15 members in the period from 2001 to 2017

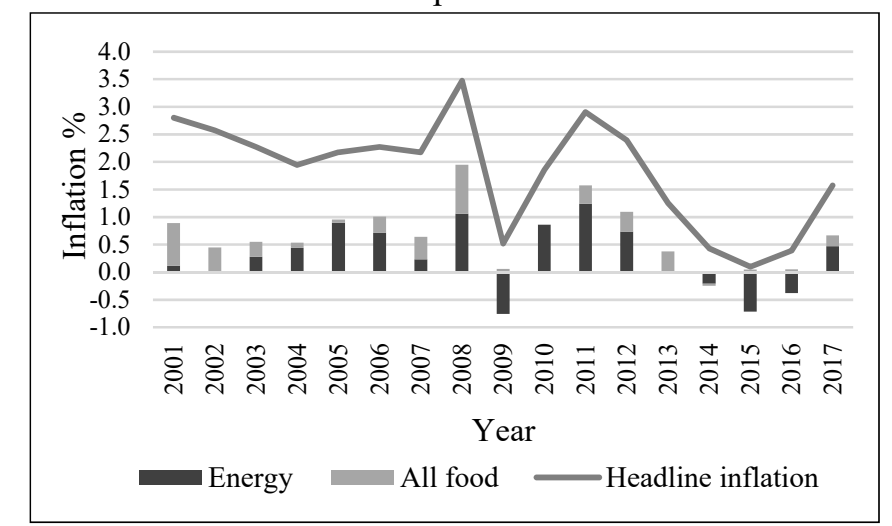

Source: Calculations by the author. Based on Eurostat, European Comission

Contrary to the EU15 countries, the share of food inflation in the new member states before accession to the EU was even lower than in the EU15 (19.4\% of total inflation). 
Figure 3. The share of food and energy prices inflation in total inflation in Hungary, Estonia, Lithuania and Latvia from 2001 to 2017

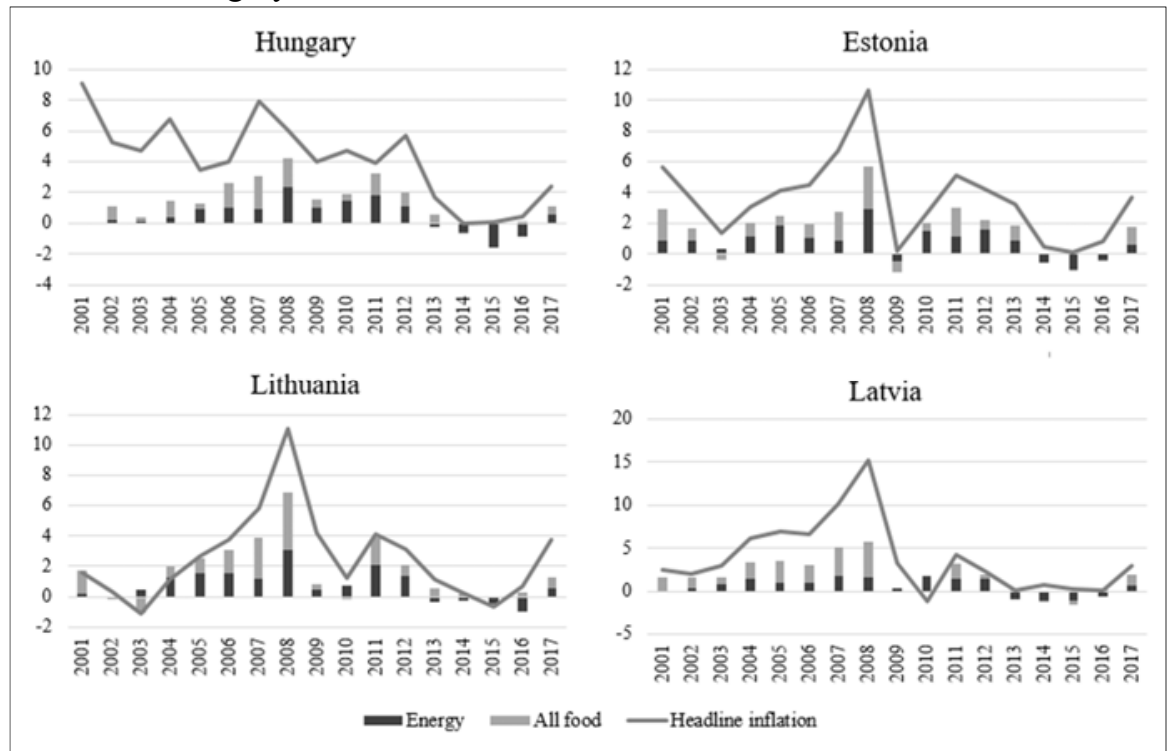

Source: Calculations by the author. Based on Eurostat, European Comission.

The exception is Latvia (47.4\% of total inflation), Romania (27.2\%) and Estonia (21.6\%). In Latvia and Estonia, inflation was at that time $2.5 \%$ and $3.5 \%$ respectfully, which is close to the EU15 average (2.5\%). Increases of food prices were most pronounced in Romania, as inflation was $24.1 \%$ in that period. Lithuania and the Czech Republic had the lowest inflation and lowest food inflation rates in the preaccession period. In Lithuania there was even a deflation, and the share of food inflation was extremely low $(2 \%)$. In the Czech Republic inflation was $2 \%$, which is less than the EU15 average, while the share of food inflation was only $5.3 \%$. 
Figure 4. The share of food and energy prices inflation in total inflation in the Czech Republic, Poland, Slovakia and Slovenia in the period from 2001 to 2017

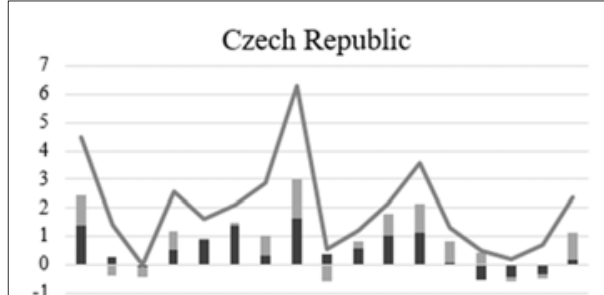

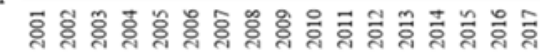

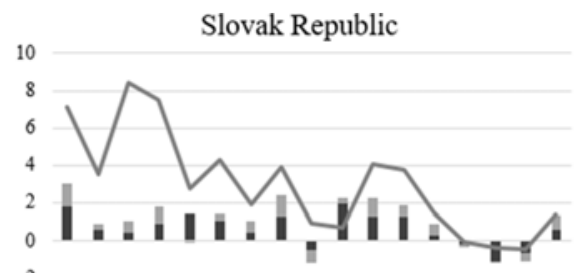

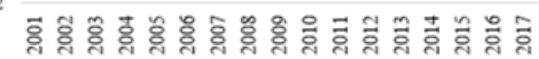

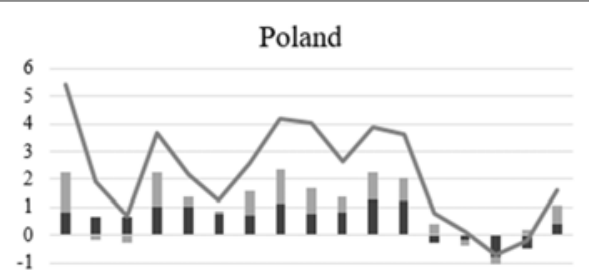

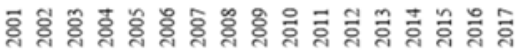

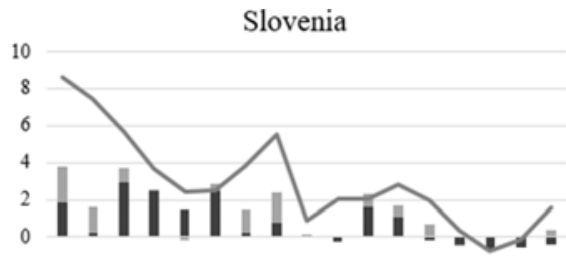

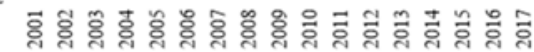

Energy $=$ All food

- Headline inflation

Source: Calculations by the author. Based on Eurostat, European Comission

After joining the EU, new member states have experienced a sudden increase of food inflation share in total inflation from $16.7 \%$ to $24.9 \%$, which is almost $50 \%$ higher. Interestingly, in the same period in the EU15 countries, the share of food inflation decreased by almost $50 \%$, and total inflation in the new EU member states was even reduced compared to the preaccession period (from $6 \%$ to $4.8 \%$ ). The largest impact of CAP occurred in Lithuania, where the share of food inflation in the preaccession period was the lowest (2\%), and in the period from 2004-2007 the highest (even $45.6 \%$ of total inflation). Also, a significant increase in food inflation in total inflation is observed in the Czech Republic (3.2 times more than before accession), Hungary (2.7 times more) and Poland (2.5 times more).

Exceptions are Slovenia and Latvia where food prices had even less impact on overall inflation than before accession. One of the reasons for Slovenia is the lower participation of food in the consumer basket compared to other observed members (Table 6), both before and after joining the EU. In Latvia, in the period before the joining, as already mentioned, there was an exceptionally high share of food inflation in the period prior to accession, so that although this share was reduced after accession, it remained at a high level (33.3\%). 
Figure 5. The share of food and energy prices inflation in total inflation in Bulgaria and Romania in the period from 2001 to 2017

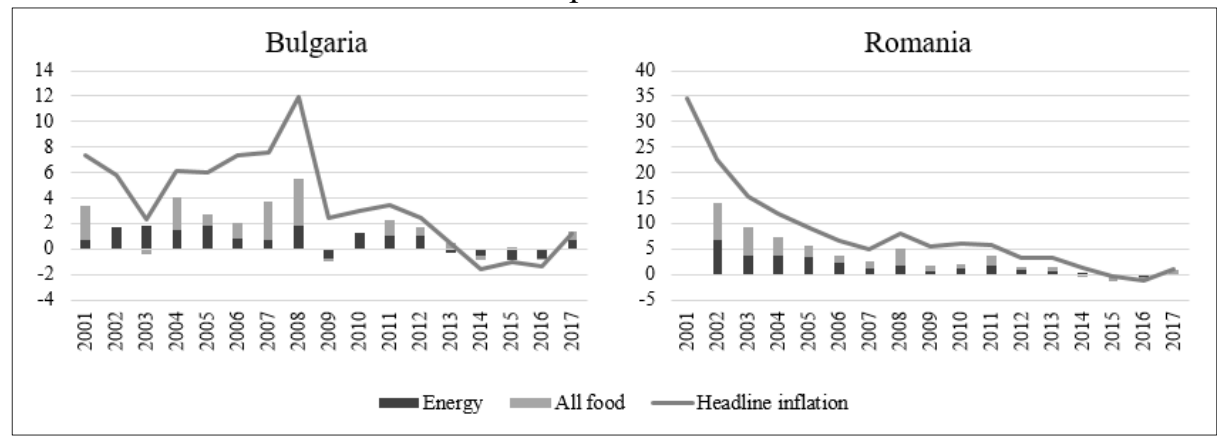

Source: Calculations by the author. Based on Eurostat, European Comission

Romania entered the EU in 2007, so that the increase in food inflation did not occur in the period 2004-2007, but somewhat later (2008-2012). In Bulgaria, the increase in the share of food inflation occurred in 2007, immediately after joining the EU, while in the coming period it was reduced. It is worth mentioning here that these are the countries where the share of food in the consumer basket before accession to the EU (2001-2003) was the highest (almost 40\%), so that the increase in food inflation in total inflation in these countries was less than what could be expected.

The greatest impact of food inflation after joining the EU can be seen especially in Lithuania, and then in all other members. The exception are Slovenia and Slovakia in which the impacts of energy prices inflation have had a higher impact on inflation after EU accession. In Romania, Poland, the Czech Republic and Estonia, it is notable that in addition to food prices inflation, energy prices inflation have contributed significantly to the total inflation.

Measuring the share of food inflation in total inflation, confirms the extremely high impact of EU accession and the application of CAP on the general price level of new member states. Based on Table 8 , in which a large number of data from previous graphs is summarized, the following can be concluded:

- In the preaccession period, food inflation in the new member states was slightly higher than in the EU15 (Table 1), while after accession (20042007), food inflation in the new member states was 3.4 times higher than in the EU15. However, in the period that followed (2008-2017), there was a continuing decline in food inflation in new member states and compliance with EU15 food inflation.

- In the period following the accession of new members (2004-2007), there was a drop in theshare of food in the consumer basket of these members by almost $20 \%$ compared to the period prior to accession (Table 6), which also 
diminished the contribution of food inflation to the overall inflation of these countries.

- The total inflation in the new member states before accession was 2.4 times higher than in the EU15, followed by a continuous decline in the inflation of these countries to almost complete equalization with the inflation of the EU15 countries in 2017 (Table 8).

Table 8. The share of food prices inflation in total inflation and the rates of total inflation in the period 2001-2017

\begin{tabular}{ccccccccc}
\hline Period & \multicolumn{2}{c}{$\mathbf{2 0 0 1 - 2 0 0 3}$} & \multicolumn{2}{c}{$\mathbf{2 0 0 4 - 2 0 0 7}$} & \multicolumn{2}{c}{$\mathbf{2 0 0 8 - 2 0 1 2}$} & \multicolumn{2}{c}{$\mathbf{2 0 1 3 - 2 0 1 7}$} \\
\hline Country & food & $\sum$ & food & $\sum$ & food & $\sum$ & food & $\sum$ \\
\hline Bulgaria & 14,5 & 5,2 & 29,3 & 6,8 & 21,9 & 4,6 & $-40,9$ & $-0,5$ \\
\hline Czech Republic & 5,3 & 2,0 & 17,0 & 2,3 & 20,4 & 2,8 & 35,0 & 1,0 \\
\hline Estonia & 21,6 & 3,5 & 23,9 & 4,6 & 22,2 & 4,6 & 23,4 & 1,6 \\
\hline Hungary & 8,7 & 6,3 & 23,4 & 5,6 & 21,4 & 4,9 & 21,5 & 0,9 \\
\hline Latvia & 47,4 & 2,5 & 33,3 & 7,4 & 25,7 & 4,8 & 39,2 & 0,8 \\
\hline Lithuania & 2,0 & 0,3 & 45,6 & 3,4 & 27,6 & 4,7 & 27,7 & 1,0 \\
\hline Poland & 10,7 & 2,7 & 26,9 & 2,4 & 24,4 & 3,7 & 49,2 & 0,3 \\
\hline Romania & 27,2 & 24,1 & 26,5 & 8,1 & 27,3 & 5,8 & $-8,4$ & 0,8 \\
\hline Slovakia & 11,3 & 6,4 & 11,1 & 4,1 & 18,0 & 2,7 & 34,7 & 0,4 \\
\hline Slovenia & 18,5 & 7,3 & 11,6 & 3,1 & 22,5 & 2,7 & 40,2 & 0,6 \\
\hline Newmembersaver & 16,7 & 6,0 & 24,9 & 4,8 & 23,1 & 4,1 & 22,2 & 0,7 \\
\hline age & 19,4 & 2,5 & 10,0 & 2,1 & 14,6 & 2,2 & 17,0 & 0,8 \\
\hline EU15average & Source: Calculations by the author. Based on Eurostat European Comission &
\end{tabular}

Source: Calculations by the author. Based on Eurostat, European Comission

Finally, in spite of the drop in share of food in the consumer basket and the decline in total inflation, food inflation is 3.4 times higher than in the EU15 countries, accounting for as much as a quarter of the inflation of new members in the period 2004-2007. In the same period, the share of food inflation in the total inflation of the EU15 countries was only $10 \%$, or 2.5 times less. In the forthcoming period, there existed a slow harmonization with the EU15, so that in the period from 2008-2012 food inflation participated in the total inflation of new members with $23.1 \%$ (60\% more than the EU15), and in the period 2013-2017 with $22.2 \%$ (30\% more than in EU15). Therefore, the high impact of food inflation on total inflation in the new EU member states is recorded only in the first years after accession, and therefore the negative impact of the CAP can only be considered short-term. 
Figure 6. Reducing inflation in old and new EU member states from 2001-2017

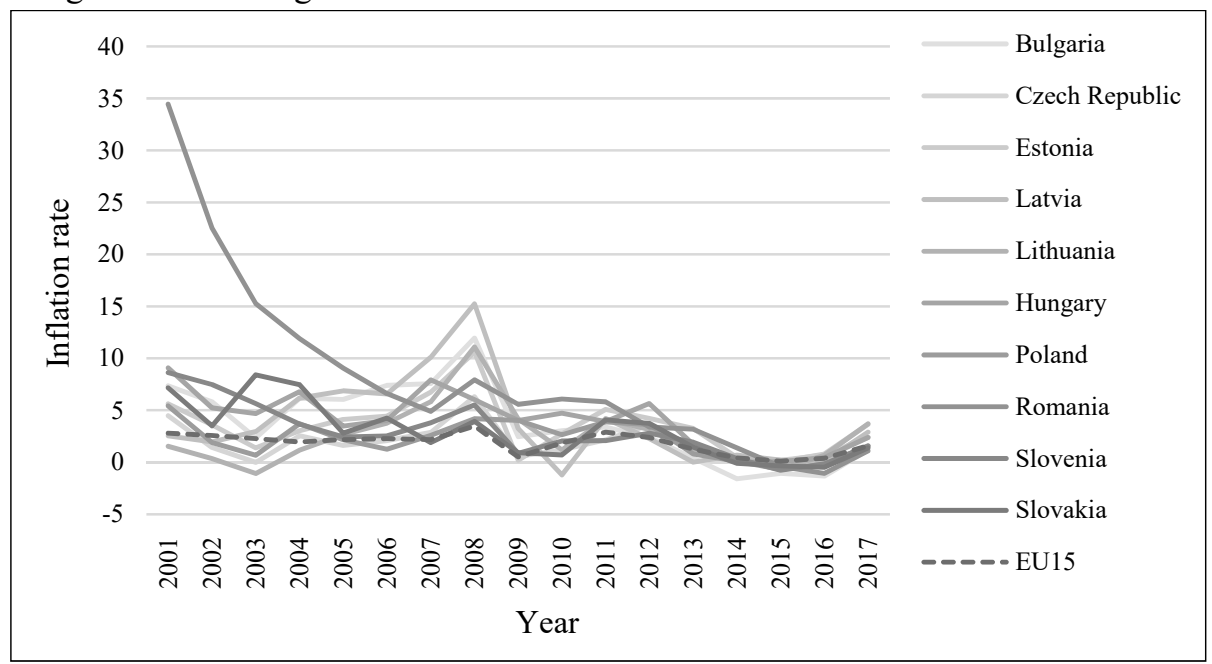

Source: Calculations by the author. Based on Eurostat, European Comission

By looking at inflation in new, as well as old EU member states, after 2008 (Figure 6), it can be concluded that the long-term effect of EU enlargement 2004 and 2007, when it comes to inflation, was positive for all members. This is reflected above all in reducing inflation and increasing the stability of the economies of new members that came shortly after a short-term price shock that caused EU accession and adaptation to CAP requirements.

\section{Results of research and discussion}

Agricultural products in many countries, especially in developing countries, but also in some developed countries, represent a significant part of the total consumer basket of the population. Agricultural products represent basic inputs in food production. Therefore, the market for agricultural products, that is, the food market is a significant determinant of stability and price levels in the total national market of a country. Changes in prices on this market also affect the prices of other products, and determine the level of inflation in the country.

The annual rate of inflation in one country often depends on what the agricultural season was in that year. Successful agricultural season allows lowering food prices due to low input prices. For this reason there is a fall in food prices, and consequently the inflation rate is falling. Providing stable and continuous supply of agricultural products simultaneously affects the stability of prices, both in the food market and in the whole market (general price level). Since, due to the seasonal character of agricultural production, the market can not equip its own forces to balance the supply and demand, and these are products of exceptional significance 
that meet the basic human need for food and affect the standard of living, it is concluded that government intervention in agriculture is necessary.

Government intervention in agriculture includes a whole system of measures and instruments that can be applied at the level of a country or group of countries such as, for example, the European Union (EU). Joining the European Union implies the termination of the implementation of the existing national agricultural policy and the beginning of the application of the so-called Common Agricultural Policy (CAP). CAP implies the existence of a single market (without customs duties on mutual trade), the community's priority in meeting the needs for agricultural products (import protection, joint ownership, customs policy) and the existence of financial solidarity (joint financing). The application of the CAP logically leads to numerous changes to the existing legislation and regulations in the field of agriculture, changes in the applied measures and instruments,implementation of agricultural policy, adjustment to the established prices of agricultural products, etc.

By observing the 10 members that joined the EU in the period from 2004 to 2007 , significant changes can be noticed by the implementation of the CAP, and above all the change in the general price level in these countries, which is also the topic of this paper. The application of the CAP has led to significant oscillations and jumps of agricultural product prices and food prices, which negatively influenced the general price level in these countries. As agricultural products make up a significant part of the consumer basket of these countries, the rise in prices after accession has had a very negative impact on inflation. However, by observing the latest available data, it is can be also noticed that this negative impact of CAP on the general price level of new members was short-termed, and that after the first shock in the first few years, a gradual price stabilization occurred. Regarding some basic agricultural products (cereals and meat), the price level several years after joining, has again become significantly lower than in the EU15 countries, as it was the case before the EU accession. The exception is the price of milk, which continued to grow and approach milk prices in the EU15.

The increase in agricultural product prices in the new EU member states can be attributed to a number of factors. Also, the growth in agricultural product prices and the inflation rate was not the same in all the new EU member states. Some countries invested more funds and undertook a number of changes in order to adapt to the CAP even before joining the EU, so that joining the EU did not cause significant negative consequences. The development of the agricultural sector, share in GDP, existing legislation in the field of agriculture, areas under agri culture, the number of agricultural workers, productivity and technological equipment, the amount of agricultural products imported and exported are some of the factors influencing the success of the implementation of the CAP in the new EU member states. 
However, what is common to all countries is that joining the EU has led to increased competition, which forced manufacturers to increase productivity, increase investment in research and increase technological equipment, improve product quality, better use of limited resources, better enforcement for food safety and environmental protection, etc. All this, in the long run, has led to the development of rural areas, the continuous supply of agricultural products and the stabilization of prices and the improvement of the living standards of the population of the new EU member states.

\section{References}

Ackrill, R. (2000) The Common Agricultural Policy, Sheffield Academic Press Ltd. United Kingdom: University of Sheffield.

Andrews, R. (2009) Encyclopedia of Business in Today's World, Common Agricultural Policy. Thousand Oaks, California: Sage Publications.

Božić, D., Bogdanov N. \& Ševarlić M. (2011) Ekonomika poljoprivrede. Beograd: Poljoprivredni fakultet.

Cantore, N. (2012) Impact of the Common Agricultural Policy on food price volatility for developing countries. London, United Kingdom: Overseas Development Institute.

Cecchetti, G. S. \& Moessner, R. (2008) Commodity prices and inflation dynamics. BIS Quarterly Review. Basel, Switzerland: Bank for International Settlements.

Chatellier, V. (2009) The reform of Market Regulation Mechanisms. The directorategeneral for internal policies, department of agriculture and rural development.

Csaki, C. \& Jambor, A. (2009) The Diversity of Effects of EU Membership on Agriculture in New Member States. Policy Studies on Rural Transition No. 2009-4, FAO Regional Office for Europe and Central Asia.

Đurić, K. \& Njegovan, Z. (2016) Ekonomika poljoprivrede. Univerzitet u Novom Sadu: Poljoprivredni fakultet.

European Commission (2008) What drives inflation in the New EU Member States? Occasional Papers No. 50. Brisel: Staff of the Directorate-General for Economic and Financial Affairs,.

Eurostat, European Comission. Preuzeto sa: https://ec.europa.eu/eurostat/data/ database, pristupljeno: 20. Oktobar 2018.

Fernández, J. (2002) The Common Agricultural Policy and EU Enlargement: Implications for Agricultural Production in the Central and Eastern European Countries. Xth EAAE Congress „Exploring Diversity in the European Agri -Food System“, Zaragoza (Spain), 28-31 Avgust 2002.

Food Price Index, Food and Agriculture Organization of the United Nations (FAO). Preuzeto sa: http://www.fao.org/worldfoodsituation//foodpricesindex/en/, pristupljeno: 10. Januar 2019.

Glosary of statistical terms, Organisation for Economic Co-operation and Development (OECD). Preuzeto sa: https://stats.oecd.org/glossary/ detail.asp?ID=864, pristupljeno: 20. Oktobar 2018.

Levis, J. \& Staehr, K. (2010)The Maastricht Inflation Criterion: What is the Effect of European Union Enlargement? Journal of Common Market Studies, Volume 48. Number 3. London, United Kingdom: University Association for Contemporary European Studies (UACES). 
Milanović, M., Ljubić, M. \& Muminović, S. (2011) Uticaj cena hrane na ciljanu inflaciju u Republici Srbiji.Ekonomika poljoprivrede broj 4/2011. Beograd: Naučno društvo agrarnih ekonomista.

Price Volatility in Food and Agricultural Markets: Policy Responses (2011) Policy Report including contributions by FAO, IFAD, IMF,OECD, UNCTAD, WFP, the World Bank, the WTO, IFPRI and the UN HLTF.

Rydén, L., Johansson, B. \& Warda, P. (2013) The EU common agricultural policy (CAP) and its effects on trade. Sweden: Jönköping International Business School, Jönköping University.

Schnepf, R. (2006) Price Determination in Agricultural Commodity Markets: A Primer. CRS Report for Congress. Washington, USA: Congressional Research Service (CRS).

Šoškić, D. (2015) Inflation impact of food prices: Case of Serbia. Economics of Agriculture 1/2015. Belgrade: Balkan Scientific Association of Agrarian Economists.

Tove, Katrine Sand T. K. \& Stoholen, B. (2008) Rising food prices - a driving force behind inflation? Oslo, Norway: Economics \& International Department, Norges Bank.

Zakić, Z. \& Stojanović, Ž. (2008) Ekonomika agrara. Univerzitet u Beogradu: Ekonomski fakultet.

\section{UTICAJ ZAJEDNIČKE AGRARNE POLITIKE EVROPSKE UNIJE NA OPŠTI NIVO CENA ZEMALJA KOJE SU PRISTUPILE U PERIODU OD 2004. DO 2007. GODINE}

Rezime: Primena tzv. Zajedničke agrarne politike (ZAP) Evropske unije podrazumeva postojanje jedinstvenog tržišta (bez carina na međusobnu trgovinu), prioritet zajednice u zadovoljavanju potreba za poljoprivrednim proizvodima (zaštita od uvoza) i postojanje finansijske solidarnosti (zajedničko finansiranje). Ulazak u Evropsku uniju za nove zemlje članice podrazumeva prestanak primene postojeće nacionalne agrarne politike i otpočinjanje sa primenom ZAP. Iako članstvo u Evropskoj uniji podrazumeva brojne prednosti, period nakon priključenja ovoj zajednici može za neke zemlje biti dosta ekonomski nestabilan. Jedan od najznačajnih problema predstavlja porast cena poljoprivrednih proizvoda kao i porast opšteg nivoa cena (inflacija). Prethodno navedeno može se potvrditi jednostavnom empirijskom analizom ekonomskih indikatora zemalja koje su zajedno pristupile EU u periodu od 2004-2007. godine.

Ključne reči: agrarna politika, ZAP, EU, Evropska unija, inflacija, opšti nivo cena. 